\section{Visión Electrónica Más que un estado sólido \\ https://doi.org/10.14483/issn.2248-4728}

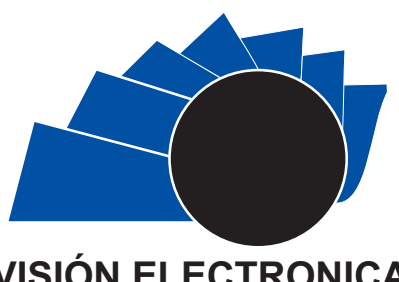

VISIÓN ELECTRONICA

A Context Vision

\title{
The Brazilian civil framework of the internet and referents in Américas region
}

\author{
Marco civil de internet en Brasil y referentes en la región Américas \\ Cristian Andrés Gutiérrez-Albarracín', Giovanni Mancilla-Gaona², \\ Beatriz Tibiriçá ${ }^{3}$
}

\section{INFORMACIÓN DEL ARTICULO}

Historia del articulo

Enviado: 24/11/2018

Recibido: 10/12/2018

Aceptado: 19/12/2018

\section{Keywords:}

Civil rights,

Equity and balance,

Freedom of expression,

Internet,

Neutrality,

Social participation.

\section{Palabras clave:}

Derechos civiles,

Equidad y balance,

Libertad de expresión,

Internet,

Neutralidad,

Participación social.

\section{ABSTRACT}

This article reviews the development of the internet civilian framework (ICF) in Brazil - to be until now the only country in the American continent with a political Internet constitution; As well as the policies that have been implemented in the Americas Region. For the above, the Brazilian policies that guarantee the rights of privacy and neutrality of the network against those of the same type in the continent that are contrasted, evidencing the failure of the latter to violate - precisely - the rights that they pretended to claim; In this sense, the Colombian case is examined. The document provides a baseline for research on regulation of the use of this service in the region, as well as on the impact it generates among Internet users.

\section{RESUMEN:}

El presente artículo revisa el desarrollo del marco civil de internet (MCI) en Brasil -por ser hasta ahora el único país del continente americano con una constitución política de internet-; así como las políticas que, al respecto, se han implementado en la Región Américas. Para lo anterior, se contrastan las políticas brasileñas con las que se garantizaron los derechos de privacidad y neutralidad de la red, frente a las del mismo tipo en el continente, evidenciándose el fracaso de estas últimas por violar-precisamente- los derechos que pretendían reivindicar; en este sentido, se examina el caso colombiano. El documento da una línea de base para investigaciones sobre regulación del uso de este servicio en la región, así como sobre el impacto que el mismo genera entre los internautas.

\footnotetext{
BSc. In Engineering, Universidad Distrital Francisco José de Caldas, Colombia. Current position: Project Leader II Getronics, Colombia. E-mail: cristianspun@gmail.com. ORCID: https://orcid.org/0000-0002-7706-2846.

${ }^{2}$ BSc. In Electronic engineering, Universidad Distrital Francisco José de Caldas, Colombia. Specialist in Engineering management systems, Pontificia Universidad Javeriana, Colombia. MBA, Politécnica de Madrid University, Spain. Current position: Professor at Universidad Distrital Francisco José de Caldas, Colombia. E-mail: gmancillag@udistrital.edu.co. ORCID: https://orcid.org/0000-0002-2552-1836.

${ }^{3}$ BSc. In Social Studies, Sao Paulo University, Brazil. Current position: Digital Collective's Director, Brazil. E-mail: beadazica@gmail.com. ORCID: https://orcid.org/0000-0002$\underline{8325-9290}$.

Cite this article as: C. A. Gutiérrez-Albarracín, G. Mancilla-Gaona and B. Tibiriçá, "The Brazilian civil framework of the internet and referents in Americas region", Visión electrónica, algo más que un estado sólido, vol. 1, no. 2, Special edition, july-december 2018. DOI revista: https://doi.org/10.14483/issn.2248-4728
} 


\section{Introduction}

The demand in the internet's usage during the last years, has been a precedent that is imperative to be examined, in order to analyze if the activities that have been made to regulate this service are really relevant. In this sense, and according to the International Telecommunications Union (ITU), the internet's penetration percentage in the world between 2000 and 2005 has moved from $6.5 \%$ to $43 \%$. This situation is not different in the Americas Region. As stated by the ITU, the percentages of the internet's penetration in this sense have increased. (see Table 1).

In 2000, the percentage of the internet's usage for some reference countries in the Americas region went as it follows: Canada 51.3\%, USA $43.08 \%$, Mexico $5.08 \%$, Brazil 2.87\% and Colombia 2.21\%. By 2013, this percentage increased dramatically: Canada $85.8 \%$, USA $84.2 \%$, Colombia $51.7 \%$, Brazil $51.6 \%$ and Mexico $43.46 \%$.

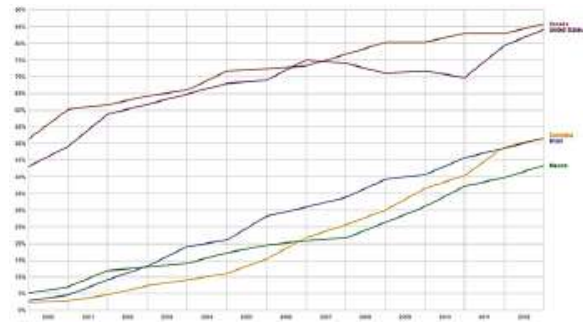

Figure 1. Percentage of the internet's penetration from 2000 to 2013 in reference countries in the American, [1].

It is understandable that during the past years, countries within the American continent have been working together in order to stablish bills that regulate the internet's service usage. To date, the country which has successfully achieved the creation of a legislation about this matter is Brazil, through the ICF, aimed towards the respect of the fundamental rights of individuals about the internet usage, such as the privacy and the neutrality in the web.

Regarding relativity, which is etymologically defined as a voice, privatus, or "something that is not public", it can be inferred that it refers to the control of information owned by a specific user when connected to the internet, as well as the capacity of having freedom of choices about the information to be shared with, and the possibility to keep as private, either an email or a social network. Neutrality, that its Latin roots come from the adjective neuter, meaning "neither one nor the other" determines the user's guarantees, so it can be able to select the access to the web pages or browsers of his preference. As it is prohibited to the ISP $^{4}$ to block the websites in an indiscriminated way and to impose its own search engine, under exclusiveness agreements with specific brands.

From this perspective, the $\mathrm{ICF}^{5}$ decriminalizes common practices within the informatics, such as: sharing copyright $^{6}$, protected videos in social networks such as Facebook and YouTube, or $\mathrm{P}_{2} \mathrm{P}^{7}$ network systems, to decide if it is accepted that specific websites share personal information with commercial purposes. To convert the song of a $\mathrm{CD}^{8}$ in a $\mathrm{MP}^{9}$ format, or freely choose a desired search engine to make queries; among others. In addition, the American continent has been working on bills that are focused on the internet usage regulation. $\left(\mathrm{SOPA}^{10}, \mathrm{PIPA}^{11}\right.$, $\left.\mathrm{ACTA}^{12}, \mathrm{CISPA}^{13}\right)$; conversely, they are guided to favor the big commercial industries, punishing the users and denying their rights. Nonetheless, the rejection awoken after these policies, forced the different governments to step back on their implementation.

As it has been exposed, this article addresses a review of the topic, in order to stablish research guidelines regarding internet regulations and the impact provoked by these bills. The structure of this article is thereupon presented: in the first section, the topic is introduced and notions about the ICF and some policies regarding the American continent are given. In the second section, the ICF and its background in Brazil are described; subsequently, there are records in the Americas region (Canada, USA and Mexico) which are referred. Next, within section 4, the background and Colombian regulations; and to close the conclusions of this research.

\section{Brazil \\ 2.1 Definition of ICF}

It is an in-force Brazilian legislation issued in 2014, whose main focus introduces the respect to the civil rights in the internet service usage. Three fundamental aspects are highlighted: Neutrality in the web, freedom of speech, and user's privacy guarantees. Besides granting the user's rights and the exercise of citizenship in digital media, issues regarding commercial exploitation are regulated, legalizing the acquisition of resources that come from web-correlated activities; so the creation of monopolies among the ISP can be avoided. Also, establishing a

\footnotetext{
ISP(Internet service provider). For Colombia UNE, ETB, MOVISTAR, among others. ICF (internet's civil framework)

${ }^{6}$ Copyright: exclusive right of an owner or concessionaire to explode a literary, scientific or artistic piece for a period of time. Copyleft, for its part, is a practice that consists in the exercise of copyright in order to allow the free distribution of copies and modified versions of a work or other work, demanding that the same rights be preserved in the modified versions.

${ }^{7} \mathrm{P} 2 \mathrm{P}$ (peer to peer) Is a network of computers in which all or some aspects work without fixed servers, but a series of nodes that behave as equals among them.

${ }^{8} \mathrm{CD}$ (Compact Disc) is an optical disk used to storage data in a digital format, that consists in any kind of information (music, images, videos, documents and other data).

${ }^{9} \mathrm{MP} 3$ (it is a way to code audio through a comprehension algorithm the loss of data, which reduces the amount of information required to represent and audio recording, but in a way that at the same time be similar enough to the quality of the original file for the most of the listeners. ${ }^{10}$ SOPA (Stop Online Piracy Act) ${ }^{11}$ PIPA (Protect IP Act)

${ }^{12}$ ACTA (Anti-Counterfeiting Trade Agreement) ${ }^{13}$ CISPA (Cyber Intelligence Sharing and Protection Act) 
connection with the citizens, increasing the democratization and the flux of information, the control of the user's data made by the ISP, the available contents, the articulated groups, as well as the copyright, [2,3].

\subsection{Background of the legislative process in Brazil.}

On February 24th, 1999, the Brazilian deputy Luiz Piauhylino De Mello Monteiro presented a draft law that intended to regulate Cybercrime in his country. It was settle as a bill (PL 84/1999), [4]. The Project regulated criminal punishment for the damaged made in the web's information, the non-granted access to a computer or website, the improper or unauthorized usage of data, the inclusion of malware ${ }^{14}$ software, and the publishing of pornographic content without prior notice, [5]. On November 5th, 2003, after four years of Legislative processes concerning Cybercrime, this draft law [4], in conjunction with minimal adjustments was approved by the Chamber of Deputies of the Brazilian National Congress (CDBNC). It was subsequently presented to the Federal Senate for its final approval.

In June, 2006, the senator Eduardo Azeredo proposed a bill that gathered disposals proper of the European convention that dealt with Cybercrime (CEDI) ${ }^{15}$, an agreement of which Brazil was not a signatory. The modifications set over-the-top definitions of crimes that might result in the Criminalization of irrelevant user's daily behaviors such as downloading files, creating a DVD $^{16}$ backup, and the manipulation of mobile devices. It would also point at the ISP the user's detection and the registration of all connections established in Brazil's internet, perpetuating a long path towards the criminalization of file exchanging, [6].

The modification of this bill had a strong support in the business and state sectors because it contained more drastic criminal punishments that the ones currently active; punishing the offenders with prison sentences and fines. However, different sectors inside the civil community, decided to get involved in the process by holding conversations with the senators part of the worker's party (WP) [6], as they were concerned about the negative outcome which included the proposed legislation.

In 2007, the senator Aloizio Mercadante Oliva, part of the WP, started a conversation with senator Azeredo, by means of including some minor adjustments, requested by the civil community, [5]. After presenting a modified text, the bill known as bill 84/99 or "Azeredo's bill”, in which it was seen as punishable behaviors as following:

-To Access to a computer system without prior notice.
- To obtain, transfer and give data or information without prior notice.

-To reveal or to misuse the information and personal data within the computer system.

-To destroy or damage other's people property or electronic third-party data.

-To spread malware in a Computerized system.

- To insert or to spread malware, followed by damages.

-Electronic Theft.

-To Interrupt or to disturb the Telegraph, the telephone, the computer, the telematics or the computer system's services.

-To forge public documents, electronic data or private documents.

- To discriminate against a user because of his race, his believes or his color throughout the web, [7].

Moreover, by 2007, an important turn has been made in the Azeredo's' bill, when Ronaldo Lemos, former teacher at Getulio Vargas's Foundation -Rio de Janeiro- carries out a publication [8] in which he argues, within a normative framework, the fact that the internet should come before a ICF, as it has been made in countries such as the Philippines and Iceland. The ICF would clearly define the functions and responsibilities that dealt with users, enterprises and other institutions with network access, so a definition of punishable regulations would be released after this. the reason of this determination is the innovation. In order to do so, as series of clear, civil guidelines must be shaped; allowing the security and the predictability of network initiatives, [8].

Subsequently, Azeredo's bill was acknowledged by its opposition parties as the AI5 DIGITAL bill- since it preceded the AI5: an agreement of absolute authority given to the military regime, [6] that understood as a characterization of the bill as it would have stablished complete control of the network. During mid-July, 2008 [9], the opponent civil community started a campaign against the incorporation of this bill. This campaign aimed to collect 160.000 signatures through a pledge with the slogan: Ban Cybercrime, in defense of freedom and the progress of knowledge in Brazil's internet, [10]. The campaign that was headed by professors André Lemos (Federal University of Bahia), Sergio Amadeus (President of the National Institute of Information Technologies) and João Caribé, internet's activist, requested a ban petition for the proposed legislation. A week after being released, the pledge had gathered about 30 thousand signatures. By July 2011, over 160.000 signatures had been collected, [6,11$13]$.

\footnotetext{
${ }^{14}$ Malware refers to any type of malicious software that intends to infect a computer, a cellphone or a Tablet. hackers use this malware to serve purposes such as: to steal one's personal information, to steal money or one's intellectual property, and to avoid user access their devices.

${ }^{15}$ The European convention is the first international treaty that intends to face Cybercrimes and other crimes such as: illegal access to computing systems, computer fraud or falsification through the harmonization of bills, the improvement in the investigation techniques and the increasing of cooperative work among the different nations.it was elaborated by the Council of Europe in Strasbourg, with the active participation of the watching states of Canada, Japan and China. It main objective is to apply a criminal policy directed to the protection of the society against Cybercrime, specially through the adoption of a suitable legislation.

${ }^{16}$ DVD (Digital Versatile/Video Disc) are discs that use a similar technology to Compact discs (CD's), to storage any kind of texts, photos, since they offer a bigger storage capacity, compared to CD's, which only count with $700 \mathrm{Mb}$, having the same dimensions.
} 
The debate was deepened when the elected-president, Luiz Inácio Lula da Silva, and her presidential cabinet chief, Dilma Rousseff, exposed a negative point of view about the implementation of the digital AI5, since it went against the freedom of information; this took place during the $10^{\text {th }}$ free software international forum (IFSF), which was held in Porto Alegre, in July 2009. [6] There, the usage of free software as a social betting tool and an economic-quality technological option that drives innovation; as well as discussing the threats on the internet's freedom was highlighted.

By the end of 2009, the legislative affairs office of the Brazilian Ministry of Justice, decides to release, in association with the Getulio Vargas's Foundation, a project based on the ICF's collaborative building in Brazil, $[6,14]$. This Project left a blog which was opened during 45 days, so internet users publish their contributions during this time; thus, a project based on the civilian contribution was created. Subsequently, most of internet users that participated in the project, requested that the user's privacy would be a priority, as well as the giving of guarantees for freedom of expression in the web. Taking this into consideration, the minister publishes the draft to its civil opponents for 45 days, so remarks will be made, and subsequently, the project could be presented to the congress in the beginning of 2010. See table of positions and interests, Table 1.

Then, during the second forum of the internet in Olinda (Brazil), in the mid of 2012, several activists developed a manifest in defense of the ICF, which was called "La Carta de Olinda" where they called for the immediate approval of the ICF, since the internet's individual rights of the users were in danger, and it was a priority to look after them, [15]. This pledge was uploaded to the net for it to be signed and shared to the people interested. The letter gets a complete support from the Deputy rapporteur to the House of Representatives, senator Alessandro Molón

\begin{tabular}{|c|c|c|c|c|c|c|}
\hline & $\begin{array}{c}\text { Users and } \\
\text { representative } \\
\text { groups }\end{array}$ & $\begin{array}{c}\text { Connection } \\
\text { companies } \\
\text { (Oi, Net, } \\
\text { etc.) }\end{array}$ & $\begin{array}{c}\text { National } \\
\text { content } \\
\text { providers } \\
\text { (Globo, } \\
\text { UOL, etc.) }\end{array}$ & $\begin{array}{c}\text { Foreign content } \\
\text { providers } \\
\text { (Google, } \\
\text { Facebook, etc.) }\end{array}$ & $\begin{array}{c}\text { Rights } \\
\text { holders } \\
\text { (recorders, } \\
\text { broadcasters } \\
\text { and authors). }\end{array}$ & $\begin{array}{c}\text { Government/ } \\
\text { judicial } \\
\text { authorities } \\
\text { and police }\end{array}$ \\
\hline $\begin{array}{c}\text { Absolute } \\
\text { neutrality }\end{array}$ & Yes/Not & Not & Yes & Yes & Indifferent & Yes \\
\hline $\begin{array}{c}\text { Connection } \\
\text { records }\end{array}$ & Yes/Not & Yes & Indifferent & Not & Yes \\
\hline $\begin{array}{c}\text { Application } \\
\text { records by } \\
\text { connection } \\
\text { companies }\end{array}$ & Yes/Not & Yes & Not & Indifferent \\
\hline $\begin{array}{c}\text { Application } \\
\text { records by } \\
\text { content } \\
\text { companies }\end{array}$ & Yes/Not & Yes & Yes & Yes & Yes & Yes/Indifferent \\
\hline $\begin{array}{c}\text { Data } \\
\text { storage in } \\
\text { the country }\end{array}$ & Yes/Not & Yes & Yes/Not & Not & Yes & Yes \\
\hline $\begin{array}{l}\text { Notice and } \\
\text { take down }\end{array}$ & Yes/Not & Not & Yes & Yes & Yes/Not & Indifferent \\
\hline
\end{tabular}

Table 1. Positions/interests of the main groups involved within the internet's regulation matter, [3].

Within the support set, it is imperative to point out the one given by the Consumer Defense Brazilian Institute $(\mathrm{CDBI})^{17}$, which participated and escorted the presentation of this draft law to the house of House of the Representatives. From there, an Online-support campaign towards the acceptance of the ICF was released; sending more than 11,500 messages to the deputies, despite the obstacles of massive economic interests, as the ones represented by telecommunication companies such as Embratel, Vivo, Claro, among others.

Due to the neutrality in the draft law [16] the well-known father of the internet Tim Berners- Lee, indicated his support to the ICF'S acceptance during his participation in the WWW2013"18, by mentioning: "The approval of internet access-free regulation would be the best birthday present for both Brazil and worldwide internet users. The beginning of a new era is set; where Brazil solidifies its reputation as a democratic and social welfare world-leader country", [17-19]. Tim Wu, an american better known as the father of the network's neutrality principle, revealed his support to the ICF's regulation in Brazil, pointing out that "it is quite important for Brazil's future, as a center of internet's innovation in the south hemisphere, the fact that the country accepts and respects the network's neutrality principles", [20].

\footnotetext{
${ }^{17}$ (CDBI) Consumer Defense Brazilian Institute

${ }^{18}$ WWW2013 (international World Wide Web) is an international that deals with topics regarding the future addressing of World Wide Web and it was created by Tim Berners in 1989.

${ }^{19}$ The NSA is a United States intelligence agency that is in charge of everything related to the security of information.
} 
Furthermore, spying has become an important reality in the network's protection; according to the statements made by Edward Snowden, in June 2013 [21]: "All global citizens are exposed to the NSA surveillance specially the diplomatics and Dilma Rouseff, in Brazilfor being a reference country in Latin America”. A month after Snowden's testimony, WikiLeaks secret material was uncovered by Julián Assange, who reveals that the elected Brazilian president, and her cabinet of ministers were spied by the NSA ${ }^{19}$.

On the other hand, another two big actions against the communication media monopoly were carried out during July and August 2013 [22-24], seeking the democratization of media and their licenses on the radio and the TV, were it was discussed that the ICF - which was in danger of becoming in a commercial framework, since from the federal's government it was intended to include express internet plan with a limit of data to be used, to be considered as an abusive practice against the regular consumer, [25].

The continuous postponement made by the House of Representatives, conditioned the ICF's collaborative assembly, due to the influence of the big telecommunication company's economic interests. Finally, on April 23rd, 2014, the Federal Senate accepted the ICF followed by its approval by president Dilma the same day, during the Netmundial Conference, which was held in Rio de Janeiro, [26]. The endorsement of this agreement provokes a positive impact for the internet users, since it strengths the rights and guarantees stablished by the constitution, see Figure 2. Among them, the user's right to freedom of speech, in order to stimulate the innovation on the internet through platforms like YouTube or Facebook, generating an environment that does not encourage the withdrawal of content that is not illegal.

In addition, the consolidation of the network's neutrality, prevents the giving of privileges or the control of content and the degradation of the speed that is part of the ICP, by means of avoiding telecommunication monopolies. Finally, it grants the privacy within the network, keeping the Brazilians' records and data stored in the countries' Data Centers, by means of avoiding the usage of the user's personal information with commercial purposes and related activities without prior consent, [27].

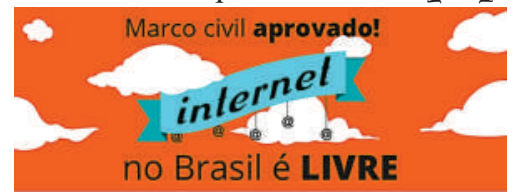

Figure 2. Poster for the internet users, [28].

\section{Americas Region References}

\subsection{Canada}

In Canada, by 1985, the code about the access to the information stipulated that the confidentiality of the user's data should be assured. If a website was used to obtain personal data of a confidential nature, it is imperative to take into account the fact that federal bills would regulate the circulation of this information. These bills were applied to the broadcasting of the information taken, as it would have been done by the editors of a magazine or a newspaper, the ones who warrant the indications to the user in the clearest way and their policies regarding any possible usage of the information obtained from the web.

Furthermore, the freedom of expression is granted, since the Canadian tribunals have determined that it is enshrined in its second article 2(b) from the Canadian Charter of Rights and Freedoms, that includes the right to receive and diffuse information, [29].

\subsection{USA}

In this country, several draft laws regarding the usage of internet were made. Despite not being accepted, they have provoked a lot of controversy worldwide, since they undermined against the right of privacy and the freedom of expression of individuals. Such bills as SOPA, PIPA y CISPA.

On the one hand, SOPA is a bill introduced by the american House of the representatives on the 26th of October, 2011, by Lamar S. Smith, president of the Justice Committee of the House of Representatives, aiming to expand the intellectual-property right owners to fight against the traffic of content on the internet, and copyright-protected products or intellectual property products. [30]. Although the bill was national wide, its application would have international consequences.

If a foreign portal hosts its Data Center Networks services in an US Data center and shared copyright-protected information, it could be either criminally investigated or its service could be unplugged, [31]. In reaction to this event, on January 18th, 2012, the companies against the SOPA bill, such as: Mozilla, Wikipedia, Google, Facebook, among others, decided to stop working for 24 hours in USA as a protest against this bill; changing their regular content for black screenshots that contain messages and their own logos, [32,33].

On January 20th, 2012, the main opponent of this polemic bill -Lamar Smith- retracted this initiative in the american congress due to the multiple critics this bill received. He also stated that the bill was retracted until a more general agreement on a solution was made. Nonetheless, to date, the bill has not been reactivated yet, [34].

PIPA, on the other hand, was another proposition that aimed to grant more tools to identify the owners of "websites dedicated to violate or traffic content"

It preceded the SOPA bill, as it was filed on May 12th, 2011 by Vermont states' democrat senator_Patrick Leahy. This bill defined as an infringing behavior, the distribution of illegal copies, Counterfeit goods, or technology that 
llowed to avoid anti-piracy shields, punishing the owners and user of websites with procedures that would exclude them from the Internet's virtual telephone directories, [35].

Taking into consideration that both PIPA and SOPA were bills filed the same year -and their approach were similarthe diverse critics and the interruption of several websites as a protest, motivated that on January 20th, 2012, the US congress indefinitely suspended these two bills, [36]. [See Figures 3,4]

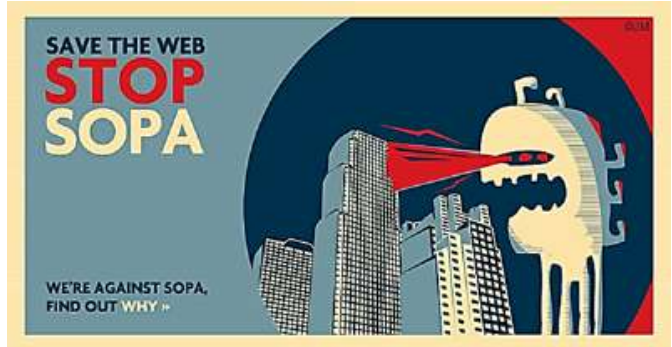

Figure 3. Poster: websites as a protest, [37].

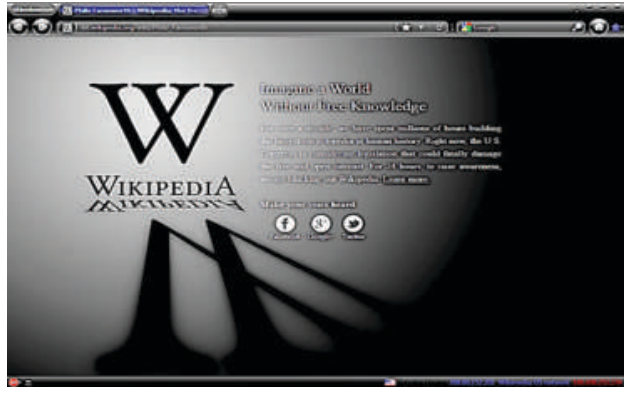

Figure 4. Poster: websites as a protest, [31].

On its behalf, the HR3523 bill, better known as CISPA [38], was a bill that allowed the exchange of information regarding the internet's traffic between the US government and the manufacture companies. Its objective was helping the government to investigate Cyber threats and ensuring the security in the networks against Cyberattacks. The legislation was introduced on November $30^{\text {th }}$, 2011 by a member of the US House of Representatives, Michael Rogers, and it was approved on April 26 $6^{\text {th }}, 2012$ in the US House of Representatives; with 248 votes in favor and 168 votes against.

This bill, as well as SOPA and PIPA bills, has been criticized for different internet's defenders groups like: $\mathrm{EFF}^{20}, \mathrm{ACLU}^{21}$, and Avaaz.org ${ }^{22}$, among others. With this legislation, there were no guarantees regarding the neutrality in the network and the civil liberties. These guardian groups exposed that CISPA had almost no limits dealing with how and when can the government take control of the internet's particular information, [39]. The elected president, Barack Obama, took a negative posture, because he considered it would allow the exchanging of information: "without the established requirements for the industry and the government to minimize and protect the information that identifies individuals"

Likewise, it would grant to agencies like NSA to access personal conversations made through the network and validate if a contact from an email address was related itself with a terrorist organization: obliterating any privacy bill ever approved for the Cybersecurity's sake, [39]. Finally, on August $2^{\text {nd }}, 2012$, CISPA was defeated in the US senate. It reached 52 out of the 60 required votes for a final discussion, [40-41].

After different drafts laws unapproved, CISA bill was crated (Cybersecurity Information Sharing Act), for which it may be told it is similar to CISPA bill, with some slight modifications. This is a federal bill that intended "to increase Cybersecurity in the US through a higher exchange of information regarding Cybersecurity threats"; increasing the government protection to those companies that, voluntarily, decide to share susceptible information to be considered as a Cyber threat with the federal government. The bill was presented to the US senate on July $10^{\text {th }}, 2014$ by California Dianne Feinstein; California's Senator representative, and it was approved on October 27th, 2015, supported by most of democrat and republican senators, obtaining 74 votes in favor and only 21 votes against, [42-43].

However, civil rights groups and technology enterprises have claimed that the terms of this agreements are vague and provide a broad maneuvering range for companies to share information with the federal authorities, without an accountability, violating once again the neutrality and privacy on the network guarantees, making of this bill a modified CISPA, [44].

\subsection{México}

Mexico, on its part, participated on an international agreement called ACTA (Anti-Counterfeiting Trade Agreement) in 2012. This agreement proposed to set protection and support to the intellectual property, in order to avoid Counterfeit goods and Internet piracy. For this goal to be achieved, ACTA would consent the strengthen of Border surveillance and would force the ISP to watch all data bundles that were charged or discharged from the cloud. Likewise, the user might be

\footnotetext{
${ }^{20} \mathrm{EFF}$ (Electronic Frontier Foundation) is an American non-profit organization, which aims to preserve rights regarding the freedom of expression, as the ones protected in the constitution's first emend, with the context of the current digital era.

${ }^{21} \mathrm{La}$ (ACLU) American Civil Liberties Union is a non-profit organization whose mission is "to defend and to preserve the rights and individual liberties guaranteed to individuals in this country by the constitution and the Us laws.

${ }^{22}$ Avaaz.org is a civil organization founded in January, 2007. It promotes the citizen's activism for topics such as the climate change, the human rights, the corruption, the poverty, the animal's rights and the peace and conflict.
} 
charged with fines, the loss of the right of an internet connection or to be sentenced to prison, [45].

This initiative was supported by countries such as: United States, Australia, and Canada including the European Union, Korea, Japan, Mexico, Singapore and Switzerland. The first ACTA drafts date from 2006, as a result of a meeting among the countries previously mentioned, [46]. On July $11^{\text {th }}$, 2012, Claude Héller, Mexican ambassador in Japan, signed the treaty, despite the unanimous suggestion made by the Senate of Mexico of not signing it; stating that ACTA treaty would turn into a threat against the internet's privacy rights, [47]. Finally, on July $20^{\text {th }}, 2012$, the Senate Standing Committee formally rejected the ACTA's signing, since it was considered that the implementation of this treaty would imply a limitation to the desirable internet's universalization of access in the Mexican Society and thereby, widening the "digital loopholes"; that is to say: the distance in the access, the usage and the appropriation of technology in the geographical, socio-economic level, articulated with other cultural inequalities, [48-49].

\section{Colombia}

In Colombia, the Anti-piracy bill 241, 2011; better known as "Lleras bill", was filed at the congress of Colombia on April 4th, 2011. This bill received its name due to the Ministry of the Interior of that age, Germán Vargas Lleras, [50]. This bill sought the regulation of the ISP responsibilities against user's copyright infringements. In addition, it presented elements of similar bills derived from ACTA, in a-more-reserved manner.

For instance, the bill just considered fines when a profit purpose was evidenced; but it will include the suspension of internet services for the recidivist, a decision that was left to in the ISP hands. As in other similar bills, this specific one triggered the rejection among the main userrepresentatives in Colombia: RedPaTodos ${ }^{23}$, Fundación Karisma $^{24}$ and Anonimous ${ }^{25}$, because of the violation of privacy, providing the ISP with the faculties to watch, to investigate and to prosecute the internet users; as well as banning the freedom of expression, deleting content considered by the ISP as offensive, [51]. Subsequently, on November $16^{\text {th }}, 2011$, The plenary of the Senate sank this bill based on a communicate made by the Senate of the Republic: "the presenters of the internet's copyright suggested to file this bill, in order to favor the freedom of expression and the privacy rights"

Consecutively, the Republican Senator Roy Barreras, draftsman of the articles, stated that "it is about considering two rights. While there is no clarity in this matter from the Government, I will go for the internet's freedom of expression" [52]. After the defeat of this bill, on March 23rd, 2012, Germán Vargas Lleras, filed the bill 201, 2012 or Lleras bill 2.0, [53]. This bill was born from a Colombian-American agreement concerning the discussion of the FTA (Free-Trade Area) which started to be negotiated in 2007. It dealt not only with copyright, but also with some exceptions regarding this subject, [54].

This bill was approved in a record time, on April $10^{\text {th }}$ 2012, by the House of the Representatives, and consequently in the Senate-complying with the government's urgent request- looking for the FTA's implementation, [55]. Nonetheless, this bill has no significant implications, since on May $8^{\text {th }}, 2012$, Jorge Robledo, Senator part of the "Polo democrático" party, sued before the Constitutional Court the Llera's bill 2.0, stating that, the exaggerated protection given to the ISP violated the fundamental right of Colombian citizens to the access to the information and their freedom to be freely disclosed, [56].

To conclude, the constitutional court overturned Llera's Bill on January $23^{\text {rd }}, 2013$, considering that procedural and substantive defects were presented in its approval in the Congress of the Republic. Besides, it highlighted that the right for education and culture was infringed, since it obstructed the access to new information through internet's web search, [57].

Despite this, the Colombian government is currently unsuccessful, regarding its idea of stubbornly presenting draft laws that affect the regular usage of internet by Colombian citizens, giving an excessive protection to copyright, in order to profit the FTA treaty with the US government.

Because none of these bills have been approved, cases like $\mathrm{UBER}^{26}$, who is currently the center of rejection on the part of the traditional taxi drivers guild, because of providing an alternative transportation service to the community; has the legal arguments to operate under the principles of neutrality in the network, as part of the bill $1450,2011,[58]$ since, despite the requests made by taxi owners and drivers to the Ministry of the $\mathrm{ICT}^{27}$, Minister David Luna has explained that he has no faculties to do such thing, since Colombia is ruled by the neutrality in the network, a principle that is closely related to the freedom of expression, according to which it should not be limited what circulates on the network, [59].

Taking this into consideration, senator Robledo filed a lawsuit for the Corporate Superintendence to cancel the legal status of UBER Colombia S.A.S, aiming to shut down this platform once for all in the country and, even if it sounds contradictory, to its defense for the

\footnotetext{
${ }^{23} \operatorname{RedPaTodos}$ (Is an initiative that emerged in response to plans by the Colombian government to change copyright legislations and to include Internet issues with budgets of the last century).

${ }^{24}$ "La Fundación Karisma", is an organization founded in 2003 and located in Bogotá (Colombia), it aims to respond to the opportunities and threats that arise in the context of "technology for development" for the exercise of human rights, from perspectives that promote freedom of expression and gender and social equities

${ }^{25}$ Anonymous is a pseudonym used worldwide by different groups and individuals to carry out individual or concerted actions or publications. firstly, conceived as a movement for fun since 2008 , Anonymous has manifested in protest actions in favor of freedom of expression, Internet independence and against several organizations.

${ }^{26}$ UBER is an international company that provides its customers with a private transport network, through a mobile application software that connects passengers with drivers of vehicles registered in their service, which offer a transportation service to individuals. ${ }^{23}$ ITC Min (Ministry of Information Technologies and Communications)
} 
internet's rights. Senator Robledo pointed out that his intention is not defending the taxi's guild, or being against mobile applications. He stated: "Technology and innovation are essential for solving society's problems and for improving taxi service, but they must be used within the Constitution and the law's regulation", [60].

In addition, on march $9^{\text {th }}, 2017$, the Colombian Ministry of Transport filed a lawsuit before the administrative court of Cundinamarca against UBER Colombia S.A.S, the ICT ministry and the National Spectrum Agency - NEA, with the purpose of protecting the collective rights, related to the usage and the defense of the goods of public property (electromagnetic spectrum), the users' rights and the freeeconomic competition. The lawsuit was admitted by this court and by the defendants. They will have 10 days, counted from the due notification, to answer the demand. In the meantime, to order the mobile services operators that, from the moment of notification: correspondingly, to immediately take the necessary actions to prevent the persistent usage of UBER's mobile application, [61].

Thus, it can be inferred that the lack of regulations as the
ICF, provokes legal loopholes in cases as in UBER in Colombia. Moreover, to reflect on the $\mathrm{ICF}^{\prime} \mathrm{s}$ implementation would bring significant advantages for the user's benefit, in relation to other bills that point towards the regulation the internet's service use in the American continent.

\section{Conclusions}

It is clear that Colombia does not have a regulation regarding copyright and the access to information that protects the rights of the civil community, since based on the Internet regulatory background and the comparative table (Table 2 ) shown below, we (Colombian people) are far from conforming and ICF. Nonetheless, the failure of some continental policies such as SOPA and ACTA bills, Lleras bill, among others, leaves good learning lessons; so a regulation that contemplates the protection of the rights of Internet users and decriminalizes common practices such as broadcasting or distributing an artistic, literary, cinematographic or musical work in digital media may be shaped, without infringing the copyright in terms of cooperation without a detriment of the neutrality and the privacy.

\begin{tabular}{|c|c|c|c|c|c|c|}
\hline & LAWS & & & & & \\
\hline & & $\mathrm{MCl}$ & SOPA & ACTA & $\begin{array}{l}\text { LLERAS } \\
\text { LAW } \\
\end{array}$ & $\begin{array}{l}\text { LLERAS } \\
\text { LAW 2,0 } \\
\end{array}$ \\
\hline & $\begin{array}{l}\text { Net neutrality } \\
\text { guarantees }\end{array}$ & Yes & No & No & No & No \\
\hline & $\begin{array}{l}\text { Guarantees } \\
\text { for free } \\
\text { expression }\end{array}$ & Yes & No & No & No & No \\
\hline & $\begin{array}{l}\text { Privacy } \\
\text { warranties }\end{array}$ & Yes & No & No & No & No \\
\hline $\begin{array}{l}\text { Categories } \\
\text { of } \\
\text { guarantees } \\
\text { and rights }\end{array}$ & $\begin{array}{l}\text { Perspective } \\
\text { on social } \\
\text { rights }\end{array}$ & $\begin{array}{l}\text { Promotes } \\
\text { innovation } \\
\text { and progress } \\
\text { solutions, in } \\
\text { addition to } \\
\text { dignifying the } \\
\text { user in the } \\
\text { virtual world }\end{array}$ & $\begin{array}{l}\text { Attacks } \\
\text { social rights } \\
\text { and } \\
\text { promotes } \\
\text { marketing } \\
\text { solutions }\end{array}$ & $\begin{array}{l}\text { Promotes } \\
\text { inequality } \\
\text { between } \\
\text { users and } \\
\text { the } \\
\text { commercial } \\
\text { industry }\end{array}$ & $\begin{array}{l}\text { Disfavor the } \\
\text { neutrality of } \\
\text { the network, } \\
\text { providing } \\
\text { legal powers } \\
\text { to ISPs }\end{array}$ & $\begin{array}{l}\text { Injures the } \\
\text { right to free } \\
\text { expression } \\
\text { and the } \\
\text { principles of } \\
\text { net } \\
\text { neutrality }\end{array}$ \\
\hline & $\begin{array}{l}\text { Social } \\
\text { consequences }\end{array}$ & $\begin{array}{l}\text { Reduce the } \\
\text { distance in the } \\
\text { access and } \\
\text { use of the } \\
\text { internet } \\
\text { fomenting the } \\
\text { progress in } \\
\text { the society }\end{array}$ & $\begin{array}{l}\text { Reproduces } \\
\text { inequality } \\
\text { and } \\
\text { generates } \\
\text { new forms } \\
\text { of poverty }\end{array}$ & $\begin{array}{l}\text { Discourages } \\
\text { access to } \\
\text { knowledge, } \\
\text { restricting } \\
\text { the } \\
\text { exchange of } \\
\text { information }\end{array}$ & $\begin{array}{l}\text { Discourages } \\
\text { access to } \\
\text { culture and } \\
\text { knowledge }\end{array}$ & $\begin{array}{l}\text { Discourages } \\
\text { access to } \\
\text { culture and } \\
\text { knowledge }\end{array}$ \\
\hline
\end{tabular}

Table 2. Comparative chart. Source: own.

It is imperative that the national government provides spaces for citizen participation referring Brazil's ICF, so in this way a stable regulation may be achieved. A regulation that gathers the user's interests such as: ensuring that privacy and freedom of expression are not violated, as to receive an equitable service for all from the ISP, based on the network's neutrality principle. Therefore, this would begin to generate a positive impact for the nation's progress, by allowing access to culture and education using the internet as a tool for this.

The usage of virtual media as a protest mechanism, focus in fact that more citizens, with no boundaries and from anywhere, have a greater attention from government entities. This way, being able to modify, to improve or to limit the bills that affected the users, such as social actions that overturned bills like SOPA and PIPA in the US. 
The ICF leaves an important lesson to the world about how to a legislation that involves the citizen participation can be made, in a collaborative-decentralized scheme. Besides, it portraits to us that things can be done the right way and in favor of the users. Perhaps the neighbor governments need to focus on this kind of propositions, as well as learning more from this practices.

The government position before UBER platform, demonstrates that the regulations regarding the internet's usage are respected, taking into consideration that this platform is upheld in the legality thanks to the neutrality in the network principle, according to which it should not be limited what circulates on it.

\section{Acknowledgments}

Thanks to Gidenutas and SciBas research groups because of their thematical and methodological advice; and coletivo digital in Brazil for its contribution and support to describe the background and the documentation of local regulatory experiences.

\section{References}

[1] ITU, "Welcome to ITU's ICT-Eye", 2018. [ $\mathrm{Online}$. Available at: http://www.itu.int/net $4 /$ itud/icteye/Default.aspx.

[2] Wikipedia, "Marco Civil de Internet", 2014. [ $\mathrm{O}$ n l i n e ]. Ava i l a ble a t : https://es.wikipedia.org/wiki/Marco_Civil_de_ Internet.

[3] Cámara de Diputados, "Marco civil brasileño de internet en español", 2014. [Online]. Available at: https://eva.fing.edu.uy/pluginfile.php/99128/ mod_resource/content/1/marco_\%20civil\%20_ internet.pdf.

[4] Camara de Diputados, "Projetos de Lei e Outras Proposições", 1999. [Online]. Available at: http://www.camara.gov.br/proposicoesWeb/fic hadetramitacao? idProposicao $=15028$.

[5] Crimes informáticos, "Projeto de lei N 84", 1999. [ O n line ]. Available a t: http://s.conjur.com.br/dl/comparacao-plsubstitutivo-crimes.pdf.

[6] P. Ortellado, "De una ley de delitos informáticos a un marco de derechos civiles en internet", 2011. [O n l in e ]. A va il a ble a t http://www.giswatch.org/sites/default/files/ap c gisw 2011 es brasil.pdf.

[7] A. de Moraes, "AI5 Digital - O que você precisa saber sobre a Lei Azeredo", 2012. [Online]. Available at: http://tuddoweb.com.br/ai-5digital-lei-azeredo/.

[8] R. Lemos, "Internet brasileira precisa de marco regulatório civil", 2007. [Online]. Available at: http://tecnologia.uol.com.br/ultnot/2007/05/2 2/ult4213u98.jhtm..

[9] J. C. Caribé, "Chamada para o Dia da Blogagem Política”, 2008. [Online]. Available at: https://xocensura.wordpress.com/2008/07/05 /chamada-para-o-dia-da-blogagem-politica/.

[10] P, Tomaz, "l digital de AI-5", 2011. [Online]. Ava i l a ble a t : http://www.cartacapital.com.br/politica/o-ai-5digital.

[11] J. C. Caribé, "Marco civil e cibercrimes, duos pesos e duas medidas", 2012. [Online]. Available at: https://meganao.wordpress.com/tag/ai5digital/.

[12] Software livre, "Mega NÃO: contra o AI-5 Digital", 2009. [Online]. Available at: http://softwarelivre.org/contra-ai-5digital/blog? npage $=10$.

Conversa Afiada, "Azeredo e o Ai-5 Digital. Monitorar web não evita crime", 2013. [Online]. A v a i l a b le a $\mathrm{t}$ : http://www.conversaafiada.com.br/politica/201 1/07/13/azeredo-e-o-ai-5-digital-monitorarweb-nao-evita-crime.

[14] Software livre, "Abierto a consulta pública para la construcción de un marco civil del Internet", 2009. [O n line]. Available at: http://softwarelivre.org/portal/noticias/aberta -a-consulta-publica-para-construcao-do-marcocivil-da-internet.

[15] J. C. Caribé, "A importância de assinar e divulgar a Carta de Olinda", 2012. [Online]. Available at: http://www.revistaforum.com.br/blog/2012/07 /a-importancia-de-assinar-e-divulgar-a-cartade-olinda/.

[16] Consumers International, "Aprueban el Marco Civil de Internet en Brasil", 2014. [Online]. A v a i l a b l e a t : http://es.consumersinternational.org/newsand-media/news/2014/03/marcointernet/.

[17] L. O. Grossmann, "Pai da web defende aprovação do Marco Civil”, 2013. [Online]. A v a i l a ble a t : http://convergenciadigital.uol.com.br/cgi/cg 
:http://convergenciadigital.uol.com.br/cgi/cgil ua.exe/sys $/$ start.htm?infoid $=33781 \&$ sid $=4$.

[18] J. Guedes, "Criador da Web defende mais uma vez o Marco Civil da Internet no Brasil", 2014. [Online]. Available at: http://www.abibahia.org.br/criador-da-web-defende-mais-umavez-o-marco-civil-da-internet-no-brasil/.

[19] C. Ritto, "Pai da web pede aprovação do Marco Civil da internet brasileira", 2013. [Online]. A va i l a ble a t : http://veja.abril.com.br/noticia/vidadigital/pai-da-web-pede-aprovacao-do-marcocivil-da-internet-brasileira/. - -internetbrasileira/.

[20] J. Varon, "Tim Wu, padre del concepto de neutralidad de la red, compatible con Internet Marco Civil en Brasil", 2013. [Online]. Available at:http://oglobo.globo.com/sociedade/tecnologi a/tim-wu-pai-do-conceito-de-neutralidade-derede-apoia-marco-civil-da-internet-no-brasil8695505.

[21] Globo, "Entenda o caso de Edward Snowden, que revelou espionagem dos EUA", 2013. [Online]. A v a i l a b 1 e a $t$ : http://g1.globo.com/mundo/noticia/2013/07/ entenda-o-caso-de-edward-snowden-querevelou-espionagem-dos-eua.html.

[22] Carta Capital, "EUA espionaram ministros de Dilma e o avião", 2015. [Online]. Available at: http://www.cartacapital.com.br/revista/857/os -alvos-do-tio-sam-9756.html.

[23] Portal Forum, "Amanhã vai ser maior, $1^{\circ}$ Grande Ato Contra o Monopólio", 2013. [Online]. A v a i l a b l e a t : http://www.revistaforum.com.br/mariafro/201 3/07/12/amanha-vai-ser-maior-1o-grande-atocontra-o-monopolio-da-midia/.

[24] Rizoma, "2 ${ }^{\circ}$ Ato Contra o Monopólio da Mídia", 2013 . [O n line ]. Available at: https://rizoma.milharal.org/2013/08/30/20ato-contra-o-monopolio-da-midia/.

[25] Congresso em foco, "Marco civil da internet: para direitos não virarem negócio", 2013. [Online]. A v a i l a b l e a $t$ : http://congressoemfoco.uol.com.br/noticias/ou tros-destaques/marco-civil-da-internet-paradireitos-nao-virarem-negocio/.

[26] Carta Capital, “ ¿O que ganhamos com a aprovação do Marco Civil da Internet?", 2013. [Online]. A v a i 1 a b l e a t : http://www.cartacapital.com.br/sociedade/oque-ganhamos-com-a-aprovacao-do-marcocivil-da-internet-9048.html.

[27] B. Gutiérrez, "Brasil aprueba el Marco Civil de Internet, modelo para la Carta Magna de la Red", 2014 . [Online]. Available at: http://www.eldiario.es/turing/Brasil-marca$\underline{r} \mathrm{i} m \mathrm{o}-\mathrm{n}$ e $\mathrm{u}$ t $\mathrm{r}$ a $\mathrm{l}$ i d a d Internet_o_243925947.html.

[28] Coletivo Digital, "Coletivo Digital Brasil", 2018. [O n line $]$. Ava il a ble a t: http://www.coletivo.art.br/.

[29] Universidad de Palermo, "Centro de Estudios en Libertad de Expresión y Acceso a la Información", 2015. [Online]. Available at: http://www.palermo.edu/cele/acceso-a-lainformacion/Paises-acceso/on/canada.html.

[30] E. Arcos, "¿Qué es y cómo funciona la ley sopa?, en términos simples y sencillos", 2012. [Online]. A va i $1 \mathrm{able}$ a t: https://hipertextual.com/2012/01/que-es-ycomo-funciona-la-ley-sopa-en-terminossimples-y-sencillos.

[31] El Tiempo, “¿Qué efectos podría tener la ley antipiratería de EE. UU. en Colombia?”, 2012. [O n l i n e $]$. Ava i l a ble a t : http://www.eltiempo.com/archivo/documento/ CMS-10965301.

[32] D. Semper, "Lista de páginas con página negra apoyando el apagón contra sopa”, 2012. [Online]. A v a i l a ble a t : http://www.aeromental.com/2012/01/18/listade-paginas-con-pagina-negra-apoyando-elapagon-contra-sopa/.

[33] Wikipedia, "Stop Online Piracy Act", 2012. [O n line ]. Available a t: https://es.wikipedia.org/wiki/Stop Online Pir acy Act.

[34] AE Tecno, "Patrocinador de la ley sopa, retira la iniciativa de ley del congreso", 2012. [Online]. Available at:

http://tecno.americaeconomia.com/articulos/pa trocinador-de-la-ley-sopa-retira-la-iniciativa-deley-del-congreso.

[35] Wikipedia, "Protect IP Act", 2012. [Online]. A v a i l a ble a t : https://es.wikipedia.org/wiki/PROTECT IPAct 
[36] J. Weisman, "After an Online Firestorm, Congress Shelves Antipiracy Bills", 2012. [Online]. A v a i l a b l e a t : http://www.nytimes.com/2012/01/21/technol ogy/senate-postpones-piracy-vote.html.

[37] Realising desings, "Stop SOPA", 2012. [Online]. A v a i l a b l e a t : https://www.realisingdesigns.com/article/stopsopa/.

[38] Congress, "H.R.3523 - Cyber Intelligence Sharing and Protection Act”, 2012. [Online]. A v a i l a b l e a $t$ : https://www.congress.gov/bill/112thcongress/house-bill/3523/text.

[39] T. C. Sottek, "The Cyber Intelligence Sharing and Protection Act: CISPA explained”, 2012. [On l in e ]. A v a i l a b l e a t : http://www.theverge.com/2012/4/27/2976718 /cyber-intelligence-sharing-and-protection-actcispa-hr-3523/in/2786603.

[40] R. Reitman, "Victory Over Cyber Spyin", 2012. [ $\mathrm{O} n \mathrm{line}$. A v a i l a ble a t : https://www.eff.org/deeplinks/2012/08/victor y-over-cyber-spying.

[41] U.S. Senate, "Roll Call Votes 112 th Congress - 2nd Session”, 2012. [Online]. Available at: http://www.senate.gov/legislative/LIS/roll_cal $\underline{1 \text { lists } / \text { roll call vote cfm.cfm? congress }=112 \& \mathrm{~s}}$ ession $=2 \&$ vote $=00187$ \#top.

[42] Wikipedia, "Cybersecurity Information Sharing Act”, 2014 . [Online]. Available at: https://en.wikipedia.org/wiki/Cybersecurity_I nformation_Sharing_Act.

[43] One Magazine, “Qué es la ley CISA y por qué la ha aprobado el Senado de EE.UU.?”, 2015. [Online $]$. A vailable a t : ht t p: / / w w w. on emagazine.es / onehacker/senado-eeuu-cisa-ciberseguridad.

[44] C. Lecher, "Senate passes controversial CISA cybersecurity bill”, 2015. [Online]. Available at: http://www.theverge.com/2015/10/27/962328 o/senate-passes-cisa-bill.

[45] Wikipedia, "Acuerdo Comercial Antifalsificación", 2008 . [Online]. Available at: https://es.wikipedia.org/wiki/Acuerdo Comerc ial_Antifalsificaci\%C3\%B3n\#cite_note6thround-6.

[46] J. Raya, "Qué es ACTA y cómo afectará el uso de internet”, 2012. [Online]. Available at: http://www.levelup.com/articulos/163822/Que -es-ACTA-y-como-afectara-tu-uso-de-Internet.
[47] P. L. Ogazón, "México firma el acuerdo comercial anti-falsificación (ACTA)", 2012. [Online]. A v a i l a b l e a t : http://www.olivares.com.mx/Es/Publicaciones /Noticias/MexicofirmaelAcuerdoComercialAnti falsificacionACTA.

[48] Observatel, "Grupo plural de trabajo para dar seguimiento a las negociaciones del acuerdo comercial anti-falsificaciones", 2018. [Online]. A v a i l a b l e a $\mathrm{t}$ : http://www.observatel.org/es/uploads/1/6048 8789-ConclusionesACTA_1_.pdf.

[49] Alto Nivel, "ACTA no procederá en México, el Senado lo rechaza”, 2012. [Online]. Available at: http://www.altonivel.com.mx/22559-acta-noprocedera-en-mexico-el-senado-lo-rechaza/.

[50] E. E. Maya, "Informe de ponencia para primer debate al proyecto de ley no. 241 de 2011”, 2011. [Online ]. Availa ble a t : http://www.imprenta.gov.co/gacetap/gaceta.m ostrar_documento?p_tipo $=22 \&$ p_numero $=241$ $\underline{\text { \&p_consec }=29091}$.

[51] Wikipedia, "Ley Lleras", 2011. [Online]. A v a i l a b l e a t : https://es.wikipedia.org/wiki/Ley_Lleras.

[52] El Tiempo, "Archivada la 'ley Lleras', que pretendía regular el uso de Internet”, 2011. [ $\mathrm{On} \mathrm{line}]$. A vaila b l e a t : http://www.eltiempo.com/archivo/documento/ CMS-10777484.

[53] M. J. Soto, "Preocupaciones sobre el Proyecto de Ley 201 de 2012", 2012. [Online]. Available at: https://karisma.org.co/preocupaciones-sobreel-proyecto-de-ley-201-de-2012/.

[54] G. S. Calderón, "Conclusiones sobre la ley Lleras 2.0”, 2012. [Online]. Available at: http://www.eltiempo.com/archivo/documento/ CMS-11629603.

[55] El Espectador, “Ley Lleras 2', aprobada en Congreso para implementar TLC con EE.UU.”, 2012 . [Online ]. Available at: http://www.elespectador.com/noticias/economi a/ley-lleras-2-aprobada-cong reso-implementartlc-eeuu-articulo-337438.

[56] S. Robledo, "Por inconstitucional, senador Robledo demandó Ley Lleras 2.0”, 2012. [ O n lin e ]. A v a i l a b l e a t : http://www.senado.gov.co/historia/item/13795 -por-inconstitucional-senador-robledodemando-ley-lleras-20. 
demando-ley-lleras-20.

[57] El Espectador, "Corte tumbó la ley de derechos de autor, conocida como Ley Lleras", 2013. [ O n li n e ]. Ava i l a ble a t: http://www.elespectador.com/noticias/judici al/corte-tumbo-ley-de-derechos-de-autorconocida-ley-llera-articulo-398450.

[58] El Espectador, “¿Por qué el Min tic no puede bloquear Uber?”, 2016. [Online]. Available at: http://www.elespectador.com/noticias/econo mia/el-mintic-no-puede-bloquear-uberarticulo-640327.

[59] Colnodo, "Neutralidad de la red en Colombia", 2018 . [Online]. Available at: https://www.colnodo.apc.org/es/novedades/ neutralidad-en-la-red-colnodo-rechaza-ladecision-en-eeuu-que-limita-el-internet-libree-igualitario.

[60] El Tiempo, "Senador Jorge Robledo presenta demanda para cerrar Uber en Colombia”, 2016. [O n l in e ]. Ava i l a ble a t: http://m.eltiempo.com/tecnosfera/novedades -tecnologia/jorge-robledo-entabla-demandapara-cerrar-uber-34305.

[61] Tribunal Administrativo de Cundinamarca, "Demanda del Ministerio de Transporte de Colombia a la sociedad comercial UBER Colombia S.A.S.”, 2017. [Online]. Available at: https://drive.google.com/file/d/oB3mRKrQ SAtvKamE5MoZVTjh4aW8/view. 